\title{
KAOLINS; EFFECT OF FIRING TEMPERATURES ON SOME OF THEIR PHYSICAL PROPERTIES
}

\author{
By R. A. Heindl, W. L. Pendergast, and L. E. Mong
}

\begin{abstract}
North Carolina, Delaware, Georgia, and Zettlitz kaolins and English china clay were fired to eight different temperatures ranging from $1,100^{\circ}$ to approximately $1,650^{\circ} \mathrm{C}$. For the unfired clays the pyrometric cone equivalents were determined and the chemical and petrographic analyses made; on the fired clays the porosity, specific gravity, petrographic analyses and thermal expansion measurements were made. X-ray diffraction patterns made of mullite and cristobalite were compared with those obtained on the North Carolina and Georgia kaolins fired to $1,300^{\circ} \mathrm{C}$. The results of the petrographic and chemical analyses show that three of the kaolins contain a greater amount of impurities than the other two, and the effect on the development of mullite and cristobalite through progressive heat treatments is consequently quite different. This difference in the development of mullite and cristobalite is indicated by both the petrographic examination and thermal expansion data. $\mathrm{X}$-ray diffraction patterns show the presence of cristobalite in one of the fired clays. The beginning of the change in the rate of thermal expansion attributed to the alpha to beta inversion of cristobalite occurs approximately $75^{\circ} \mathrm{C}$. below the usually accepted lower limit of temperature range of this inversion. A limited amount of data are given on dickite (Mexican kaolin), halloysite, and silica.
\end{abstract}

\section{CONTENTS}

I. Introduction

II. Materials.... 200

III. Preparation of specimens

IV. Methods of testing

V. Results ........ 201

1. Chemical analyses.......... 201

2. Petrographic analyses_.......... 201

3. Pyrometric cone equivalents..... 204

4. Specific gravity and porosity

5. Thermal expansion

6. X-ray studies....... 211

VI. Similarity of expansion between $100^{\circ}$ and $200^{\circ} \mathrm{C}$. of precipitated silica and the Georgia and Zettlitz kaolins . 212

VII. Summary

VIII. Acknowledgments.

\section{INTRODUCTION}

The effect of temperature of firing on the mineralogical composition of fire clays was discussed briefly in a report ${ }^{1}$ recently published dealing with fire clays. Because of the interesting results obtained with such clays it was considered desirable to continue the study with clays or the kaolin type in order to gain information on the effect of heating materials whose composition more nearly approaches

1 “Fire Clays; Some Fundamental Properties at Several Temperatures." B. S. Jour. Research, vol. 5 (RP194); also J. Am. Ceram. Soc., vol. 13 (10), pp. 725-750, 1930. 
that of pure kaolinite. Even though kaolins are relatively pure clays, they differ quite appreciably in composition, depending on the source of supply and purifying process involved; and the results obtained in a study of them vary accordingly.

\section{MATERIALS}

The materials studied were taken from the reoular stock available at the bureau, and included Georgia (soft), Delaware, North Carolina, and Zettlitz kaolins and English china clay. A few tests were also made on dickite, Georgia (hard) kaolin, halloysite, silicic acid, and flint.

\section{PREPARATION OF SPECIMENS}

Specimens suitable for expansion measurements with the interferometer, and bar specimens 2 inches long and 1 inch in cross section, were made of each of the five kaolins. These were fired in a furnace whose temperature was increased at the rate of $20^{\circ} \mathrm{C}$. an hour up to $1,400^{\circ} \mathrm{C}$. Two of the specimens for expansion studies and one of the bar specimens of each kaolin were withdrawn at each of the following temperatures: $1,100^{\circ}, 1,150^{\circ}, 1,200^{\circ}, 1,250^{\circ}, 1,300^{\circ}$, and $1,400^{\circ} \mathrm{C}$. and placed in a second furnace having a temperature of approximately $600^{\circ} \mathrm{C}$. At the end of 15 hours, when the temperature was approximately $100^{\circ} \mathrm{C}$., the specimens were removed (referred to hereafter as "cooled rapidly"). The remaining specimens of the five clays were fired to cone $18 \frac{1}{2}$ (approximately $1,500^{\circ}$ C.) at the rate of approximately $10^{\circ} \mathrm{C}$. an hour and allowed to cool slowly with the furnace. With the exception of the English china clay, specimens for expansion studies were also fired at $1,200^{\circ}$ and $1,300^{\circ} \mathrm{C}$. for two hours, and at $1,400^{\circ} \mathrm{C}$. for five hours, and in each instance were cooled with the furnace in approximately 48 hours (referred to hereafter as "cooled slowly"). In addition, specimens of Georgia kaolin containing 5, 10 , and 15 per cent of muscovite were prepared and fired at $1,400^{\circ} \mathrm{C}$. for five hours.

Specimens were also prepared of a mixture of kaolin and precipitated alumina and fired at $1,300^{\circ} \mathrm{C}$. for two hours and others at cone 30 (approximately $1,650^{\circ} \mathrm{C}$.) for one-half hour. Alumina was added to secure the proper alumina-silica ratio $(3: 2)$ in order to obtain a body consisting entirely of mullite after firing. This was done with all five of the kaolins and the amount added was dependent on the percentage of silica found by chemical analysis.

\section{METHODS OF TESTING}

Thermal expansivity measurements of the materials were made from atmospheric temperature to $900^{\circ} \mathrm{C}$. with the interferometer. ${ }^{2}$ The procedure followed in making chemical analyses was, in general, the method of analysis for refractories described by Lundell and Hoffman. ${ }^{3}$ The specific gravities were determined according to the method of test for pigments, ${ }^{4}$ promulgated by the American Society for Testing Materials. The procedure for making the porosity determinations was as follows: The specimens were saturated by boiling

\footnotetext{
${ }^{2}$ Described in B. S. Sci. Paper No. 485, by G. E. Merritt.

3 Analysis of Bauxite and of Refractories of High Alumina Content, B. S. Jour. Research, vol. 1 (RP 5); July, 1928.

1 American Society for Testing Materials Standards 1930, Pt. II, A. S. T. M. Designation D 153-27.
} 
in water under reduced pressure for two hours and permitting them to remain over night under a gradually increasing pressure. The volume was obtained by water displacement. The porosity expressed in per cent was computed by dividing the weight of water absorbed (dry weight minus saturated weight) by the volume of the specimen. The pyrometric cone equivalents ${ }^{5}$ "softening points" were determined according to the A.S. T. M. standard method, serial designation C $24-28 .^{6}$

\section{TABLE 1.-Chemical analyses of kaolins}

\begin{tabular}{|c|c|c|c|c|c|c|c|}
\hline Name of material & $\begin{array}{l}\text { Georgia } \\
\text { kaolin } 1\end{array}$ & $\begin{array}{l}\text { North } \\
\text { Carolina } \\
\text { kaolin } 1\end{array}$ & $\begin{array}{c}\text { Delaware } \\
\text { kaolin }^{1}\end{array}$ & $\begin{array}{l}\text { English } \\
\text { China } \\
\text { clay } 1 \\
\end{array}$ & $\begin{array}{l}\text { Zettlitz } \\
\text { kaolin }\end{array}$ & Dickite $^{3}$ & $\begin{array}{l}\text { Halloy- } \\
\text { site }^{3}\end{array}$ \\
\hline $\begin{array}{l}\text { Ignition loss } \\
\mathrm{SiO}_{2} \\
\mathrm{Fe}_{2} \mathrm{O}_{3} \\
\mathrm{Al}_{2} \mathrm{O}_{3} \\
\mathrm{TiO}_{2} \mathrm{~N}\end{array}$ & $\begin{array}{r}\text { Per cent } \\
13.71 \\
45.30 \\
.27 \\
39.14 \\
1.54\end{array}$ & $\begin{array}{r}\text { Per cent } \\
13.03 \\
48.46 \\
.51 \\
36.53 \\
.06\end{array}$ & $\begin{array}{r}\text { Per cent } \\
11.84 \\
48.53 \\
1.57 \\
35.79 \\
.33\end{array}$ & $\begin{array}{r}\text { Per cent } \\
12.37 \\
47.00 \\
.96 \\
37.72 \\
.15\end{array}$ & $\begin{array}{r}\text { Per cent } \\
12.95 \\
46.90 \\
.65 \\
37.40 \\
.18\end{array}$ & $\begin{array}{r}\text { Per cent } \\
14.08 \\
45.04 \\
\text { Trace. } \\
40.70 \\
\text { Trace. }\end{array}$ & $\begin{array}{r}\text { Per cent } \\
14.64 \\
41.62 \\
.62 \\
38.66 \\
\end{array}$ \\
\hline $\begin{array}{l}\mathrm{CaO} \\
\mathrm{MgO} \\
\mathrm{K}_{2} \mathrm{O}_{2} \\
\mathrm{Na}_{2} \mathrm{O} \\
\mathrm{H}_{2} \mathrm{O}\end{array}$ & $\begin{array}{l}.13 \\
.04 \\
.15 \\
.10\end{array}$ & $\begin{array}{r}.13 \\
.03 \\
1.34 \\
.21\end{array}$ & $\begin{array}{r}.15 \\
.22 \\
1.80 \\
.19\end{array}$ & $\begin{array}{r}.19 \\
.18 \\
1.57 \\
.23\end{array}$ & $\begin{array}{l}.29 \\
.27 \\
.84 \\
.44\end{array}$ & $\begin{array}{c}.22 \\
\text { Trace. } \\
\text { Trace. }\end{array}$ & $\begin{array}{r}.10 \\
.08 \\
4.26\end{array}$ \\
\hline
\end{tabular}

1 Analysis made by J. F. Klekotka.

Analysis made by Dr. J. I. Hoffman and taken from Bureau of Standards Technical Ne ws Bulletin 138, p. $146 ; 1928$.

These materials and chemical analyses were furnished by C. S. Ross, of the U. S. Geological Survey. The dickite originated in Chihuahua, Mexico, and the halloysite in Adams County, Ohio.

\section{RESULTS AND DISCUSSION}

\section{CHEMICAL ANALYSES}

The chemical analyses of the five kaolins on which the greater part of this study was made are given in Table 1 . Considering kaolinite $\left(\mathrm{Al}_{2} \mathrm{O}_{3} \cdot 2 \mathrm{SiO}_{2} \cdot 2 \mathrm{H}_{2} \mathrm{O}\right)$ as approximately 14.0 per cent water, 46.5 per cent silica, and 39.5 per cent alumina, it is found that the composition of the Georgia and Zettlitz kaolins approaches the composition of the kaolinite more closely than do any of the other three. This point is of importance because the data obtained in the several tests vary quite decidedly for the different kaolins.

\section{PETROGRAPHIC ANALYSES}

Petrographic analyses were made of both the unfired clays and of the same clays after firing at progressively increasing temperatures. The petrographic examinations were made to obtain information on the foreign materials present and to determine, if possible, the temperature at which the clay when fired is converted to mullite with the excess silica remaining free in accordance with the following equations:

$$
\begin{aligned}
3\left(\mathrm{Al}_{2} \mathrm{O}_{3} \cdot 2 \mathrm{SiO}_{2} \cdot 2 \mathrm{H}_{2} \mathrm{O}\right)+\text { heat } & =3\left(\mathrm{Al}_{2} \mathrm{O}_{3} \cdot 2 \mathrm{SiO}_{2}\right)+6 \mathrm{H}_{2} \mathrm{O} \\
3\left(\mathrm{Al}_{2} \mathrm{O}_{3} \cdot 2 \mathrm{SiO}_{2}\right)+\text { heat } & =3 \mathrm{Al}_{2} \mathrm{O}_{3} \cdot 2 \mathrm{SiO}_{2}+4 \mathrm{SiO}_{2}
\end{aligned}
$$

\footnotetext{
5 In this report the expression pyrometric cone equivalent (P. C. E.) is to be interpreted according to the tentative definition given in the Proceedings of the American Society for Testing Materials, pt. 1, vol. 30 , 1930 , p. 473, which is "In the case of refractories the number of that standard cone whose tip would touch the supporting plaque simultaneously with a cone of the material being investigated when tested in accordance with the standard method of test for softening point of fire-clay brick of the A. S. T. M.

6 Described in American Society for Testing Materials Standards for 1930, Pt. II, p. 210.
} 
The analyses follow:

Georgia Kaolin.-Unfired.-Contains approximately 2 per cent mica and less than 1 per cent quartz. No feldspar noted, but a small amount of a fine-grained mineral (possibly rutile) present.

Fired to $1,100^{\circ} \mathrm{C}$. (cone 1) and to $1,150^{\circ} \mathrm{C}$. (cone 6).- No mullite noted. Made up largely of isotropic grains having an index of refraction of about 1.55. Occasional needles having a very high index and a very high birefringence (possibly rutile) present.

Fired to $1,200^{\circ} \mathrm{C}$. (cone 10).-No visible mullite development. The amorphous grains have an index of refraction of about 1.57. The high index, highly birefringent aggregates appear to be smaller and less numerous.

Fired to $1,250^{\circ} \mathrm{C}$. (cone 12) and $1,300^{\circ} \mathrm{C}$. (cone 13). - The faintest trace of mottled structure noted which, perhaps, indicates the beginning of mullite development. The mottled structure becomes fairly distinct after firing at $1,300^{\circ} \mathrm{C}$. The grains are made up of bundles of subparallel fibers showing low birefringence.

Fired to $1,400^{\circ} C$. (cone 16). - Fine, somewhat irregular fibers of mullite are visible. Material made up of only two visible phases, namely, mullite and a low index interstitial material.

Fired at cone 18-19 (approximately 1,500 ${ }^{\circ}$ C.).- Muliite fibers are perceptibiy larger and better developed than in the material fired at $1,400^{\circ} \mathrm{C}$.

Fired at cone 30 (approximately $1,650^{\circ} \mathrm{C}$.). - The average thickness of the mullite fibers is increased to approximately $4 \mu$. The material containing the added alumina consists almost entirely of large, welldeveloped mullite crystals. Only a very small amount of glass and uncombined alumina present.

English China Clay.-Unfired material.-Estimated to contain from 9 to 11 per cent of muscovite, less than 1 per cent of quartz, and a small amount of feldspar (probably less than 2 per cent).

Fired to $1,100^{\circ}$ C.-Material somewhat heterogeneous in composition and largely composed of platy, colorless grains.

Fired to $1,150^{\circ} C$.- Not much change from the preceding firing. The stained grains show a mottled structure.

Fired to $1,200^{\circ} C$.- A faint but unmistakable mottled structure perceptible in all the platy grains.

Fired to $1,250^{\circ}$ C.- The material is more uniform in structure and in index of refraction than that fired at the lower temperatures. Bundles of subparallel fibers with low birefringence noted.

Fired to $1,300^{\circ} \mathrm{C}$.- - Mottled structure of lower fired samples replaced by irregular and extremely thin fibrous structure (probably mullite).

Fired to $1,400^{\circ}$ C.-The sample consists of only mullite and an interstitial, low index, isotropic material.

Fired at cones 18-19 $\left(1,500^{\circ} C\right.$.).-Very little change from the $1,400^{\circ} \mathrm{C}$. firing except that the mullite needles are better developed.

Fired at cone 30 (approximately $1,650^{\circ}$ C.). - Very similar to the material fired at $1,500^{\circ} \mathrm{C}$., except that the mullite needles are somewhat larger and better developed. The mixture of kaolin and alumina consists almost entirely of large, well-developed mullite crystals. Only a very small amount of uncombined glass and alumina noted.

North Carolina Kaolin.-Unfired material.-Estimated to contain from 7 to 9 per cent of muscovite, 10 to 12 per cent quartz, and, perhaps, as much as 10 per cent feldspar (largely microcline). 
A small amount of an unidentified mineral with a high index of refraction (probably hematite or hydrated ferric oxide) present.

Fired to $1,100^{\circ}$ C.- Heterogeneous in structure. Kaolinite and mica grains still retain their platy structure. Feldspar grains have been largely fused to a glass. Quartz grains appear unchanged.

Fired to $1,150^{\circ} \mathrm{C}$. and to $1,200^{\circ} \mathrm{C}$.- Quartz remains unchanged. A mass of short fibers developed within the fused feldspar grains which are only visible with the highest magnification, indicating the beginning of the formation of mullite.

Fired to $1,250^{\circ} \mathrm{C}$.- Mullite development has begun in the kaolinite grains and progressed further in the fused feldspar grains. The quartz grains are surrounded by a narrow rim of low index material either the result of transformation or solution.

Fired to $1,300^{\circ} \mathrm{C}$. and $1,400^{\circ} \mathrm{C}$.- - Triangular networks of mullite have developed in the kaolinite grains which continued to develop with the $1,400^{\circ} \mathrm{C}$. firing.

Fired to $1,500^{\circ} \mathrm{C}$. (approximately). - A marked change in the structure and microscopic appearance of the material noted. Only fibers of mullite imbedded in an interstitial low index material (probably glass) present.

Fired at $1,650^{\circ}$ C. (approximately). - The mullite grains show definite evidence of solution. The specimen originally containing the mixture of kaolin and alumina after firing consists almost entirely of large, well-developed crystals of mullite. Small amounts of glass and uncombined alumina noted.

Delaware KaOlin.-Unfired material.-Estimated to contain from 15 to 17 per cent of mica, from 12 to 14 per cent of quartz, and an indeterminate quantity of feldspar (probably less than 5 per cent). Very small amounts of what may be rutile and hematite noted.

Fired to $1,100^{\circ}$ C.-Kaolinite grains still retain a platy structure. Quartz grains unaltered from the raw materia!.

Fired to $1,150^{\circ}$ C.- No visible development of mullite in the kaolinite grains. Edges of quartz grains indicate incipient fusion.

Fired to $1,200^{\circ}$ C.- - Mottled structure in kaolinite grains indicates the initial development of mullite.

Fired to $1,250^{\circ} \mathrm{C}$. and to $1,300^{\circ} \mathrm{C}$.- Further gradual development of mullite grains.

Fired to $1,400^{\circ}$ C.-Small fibers of mullite embedded in a low index, interstitial material (probably glass) are the only two phases present.

Fired at $1,500^{\circ}$ and $1,650^{\circ} \mathrm{C}$. (approximately).-The mullite and glass phases are similar to that noted in the $1,400^{\circ} \mathrm{C}$. firing except that the mullite needles show much better development. The kaolin with the added alumina after firing to approximately $1,650^{\circ} \mathrm{C}$. shows a much greater percentage of mullite crystals, but considerable amounts of uncombined alumina and glass also present.

ZetTLITZ KaOLIN-Unfired material.-Estimated to contain from 1 to 2 per cent of muscovite and less than 1 per cent of quartz. No feldspar noted, but very small amounts of hornblende, hematite, and dolomite present.

Fired to $1,100^{\circ} \mathrm{C}$.- The original kaolinite grains largely converted to isotropic masses with a few remnants of the original platy structure remaining. No visible mullite development and no mottled structure noted. 
Fired to $1,150^{\circ}, 1,200^{\circ}$, and $1,250^{\circ} \mathrm{C}$. The material after firing at $1,150^{\circ} \mathrm{C}$. appears very similar to that fired to $1,100^{\circ}$ except that cloudy birefringent areas have largely disappeared. After firing at $1,200^{\circ} \mathrm{C}$. the grains show a mottled structure indicating the possible presence of mullite and with the $1,250^{\circ} \mathrm{C}$. firing a fairly distinct fiber formation evident.

Fired to $1,300^{\circ}$ C.-Grains not uniform in structure, but the mullite structure and fiber development have progressed decidedly. Isotropic low index inclusions, irregular in shape, persist and appear to be more abundant than in preceding firings.

Fired to $1,400^{\circ}, 1,500^{\circ}$, and $1,650^{\circ} \mathrm{C}$.- Mullite and an interstitial material of lower index are the only two phases present. The mullite needles grow in size as the temperature of firing is raised. The kaolin-alumina mix composed principally of large, well-developed crystals of mullite. Appreciable amounts of glass and uncombined alumina noted.

\section{PYROMETRIC CONE EQUIVALENTS}

The P. C. E. of each of the five kaolins was 35 (approximately $1,785^{\circ}$ C.).

No change in the P. C. E. of Georgia kaolin was observed by additions of either 5,10 , or 15 per cent of muscovite, the P. C. E. of which was 14 (equivalent, under the conditions of our test, to approximately $1,400^{\circ} \mathrm{C}$.). This was the only kaolin to which muscovite was added.

\section{SPECIFIC GRAVITY AND POROSITY}

The true specific gravity and the apparent porosity of the specimens of kaolins after firing at each of six temperatures, namely, $1,150^{\circ}, 1,200^{\circ}, 1,250^{\circ}, 1,300^{\circ}, 1,400^{\circ}$, and $1,500^{\circ}$ C., are given in Table 2.

TABLE 2.-Specific gravity and porosity ${ }^{1}$ after firing

\begin{tabular}{|c|c|c|c|c|c|c|c|c|c|c|c|c|}
\hline \multirow{3}{*}{ Kaolin identity } & \multicolumn{12}{|c|}{ Temperature of firing ${ }^{\circ} \mathrm{C}$. } \\
\hline & \multicolumn{2}{|c|}{1,150} & \multicolumn{2}{|c|}{1,200} & \multicolumn{2}{|c|}{1,250} & \multicolumn{2}{|c|}{1,300} & \multicolumn{2}{|c|}{1,400} & \multicolumn{2}{|c|}{1,500} \\
\hline & 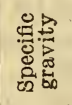 & 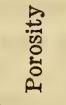 & 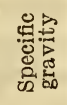 & 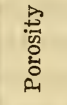 & 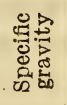 & 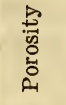 & 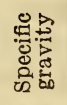 & 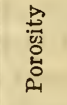 & 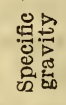 & 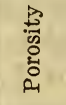 & 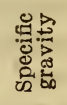 & 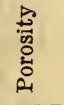 \\
\hline & & $\begin{array}{l}\text { Per } \\
\text { cent }\end{array}$ & & $\begin{array}{l}\text { Per } \\
\text { cent }\end{array}$ & & $\begin{array}{l}\text { Per } \\
\text { cent }\end{array}$ & & $\begin{array}{l}\text { Per } \\
\text { cent }\end{array}$ & & $\begin{array}{l}\text { Per } \\
\text { cent }\end{array}$ & & $\begin{array}{l}\text { Per } \\
\text { cent }\end{array}$ \\
\hline North C & 2. 709 & 46.45 & 2. 711 & $\begin{array}{l}45.78 \\
7.78\end{array}$ & 2. 732 & 43.50 & 2.696 & 41. 18 & 2.706 & 34.60 & 2. 707 & 31.80 \\
\hline re...-. & $\begin{array}{l}2.712 \\
2.748\end{array}$ & $\begin{array}{l}39.47 \\
39.00\end{array}$ & $\begin{array}{l}2.784 \\
2.787\end{array}$ & $\begin{array}{l}37.18 \\
33.32\end{array}$ & $\begin{array}{l}2.719 \\
2.801\end{array}$ & $\begin{array}{l}32.10 \\
32.30\end{array}$ & $\begin{array}{l}2.705 \\
2.815\end{array}$ & $\begin{array}{l}24.02 \\
30.18\end{array}$ & $\begin{array}{l}2.675 \\
2.781\end{array}$ & $\begin{array}{l}6.79 \\
9.10\end{array}$ & $\begin{array}{l}2.689 \\
2.793\end{array}$ & $\begin{array}{l}1.50 \\
2.57\end{array}$ \\
\hline Zett & 2.748 & 37.17 & 2.750 & 34.42 & 2.762 & 30.70 & 2.733 & 22.12 & 2. 695 & 1.74 & 2. 749 & 0.0 \\
\hline English.-.- & 2.714 & 41. 15 & 2. 723 & 37.00 & 2.725 & 28.40 & 2. 734 & 22.72 & 2. 702 & 10.04 & 2.700 & 50 \\
\hline
\end{tabular}

1 For method of determining, see J. Am. Ceram. Soc., vol. 11, No. 6, p. 456; 1928.

North Carolina kaolin shows the smallest change in porosity over the range of firing temperatures used and English china clay the largest, although there is not a great deal of difference between the English china clay and the Georgia, Zettlitz, and Delaware kaolins. The values given represent determinations on one specimen only for each of the firings. 
In general, the specific gravity slightly increases with increasing firing temperature to $1,250^{\circ} \mathrm{C}$., decreases to $1,400^{\circ} \mathrm{C}$., and increases again at $1,500^{\circ} \mathrm{C}$.

The specific gravity values represent the average of two determinations and in no case was there a greater variation from the average than \pm 0.005 .

\section{THERMAL EXPANSION}

The linear thermal expansion of the materials studied is shown in Table 3. Values are given for three different ranges of temperature obtained for each of the kaolins after firing at several different temperatures. Curves representing the expansion data are shown in Figures 1 to 5 , inclusive.

TABLE 3.-Coefficient of linear thermal expansion of kaolins fired at different temperatures

\begin{tabular}{|c|c|c|c|c|c|c|c|c|c|c|c|c|c|c|c|}
\hline \multirow{4}{*}{ Kaolins fired to ${ }^{\circ} \mathrm{C}:-$} & \multicolumn{15}{|c|}{ Average coefficient of expansion ${ }^{1}$ of kaolin } \\
\hline & \multicolumn{3}{|c|}{ North Carolina } & \multicolumn{3}{|c|}{ Delaware } & \multicolumn{3}{|c|}{ Georgia } & \multicolumn{3}{|c|}{ Zettlitz } & \multicolumn{3}{|c|}{ English } \\
\hline & \multicolumn{15}{|c|}{ Temperature range $\left({ }^{\circ} \mathrm{C}.\right)$} \\
\hline & $\begin{array}{c}100 \\
\text { to } \\
200\end{array}$ & $\begin{array}{c}550 \\
\text { to } \\
600\end{array}$ & $\begin{array}{c}20 \\
\text { to } \\
900^{2}\end{array}$ & $\begin{array}{c}100 \\
\text { to } \\
200\end{array}$ & $\begin{array}{c}550 \\
\text { to } \\
600\end{array}$ & $\begin{array}{c}20 \\
\text { to } \\
900^{2}\end{array}$ & $\begin{array}{c}100 \\
\text { to } \\
200\end{array}$ & $\begin{array}{c}550 \\
\text { to } \\
600\end{array}$ & $\begin{array}{c}20 \\
\text { to } \\
900^{2}\end{array}$ & $\begin{array}{c}100 \\
\text { to } \\
200\end{array}$ & $\begin{array}{c}550 \\
\text { to } \\
600\end{array}$ & $\begin{array}{c}20 \\
\text { to } \\
900^{2}\end{array}$ & $\begin{array}{c}100 \\
\text { to } \\
200\end{array}$ & $\begin{array}{c}550 \\
\text { to } \\
600\end{array}$ & $\begin{array}{c}20 \\
\text { to } \\
900^{2}\end{array}$ \\
\hline $\begin{array}{l}1,100 \\
1,200 \\
1,250^{3} \text { (slow cooling) }\end{array}$ & $\begin{array}{l}3.7 \\
3.3 \\
3.5 \\
4.6 \\
4.9\end{array}$ & $\begin{array}{r}10.1 \\
9.3 \\
7.8 \\
7.3 \\
7.0\end{array}$ & $\begin{array}{l}4.6 \\
4.1 \\
4.4 \\
4.8 \\
4.5\end{array}$ & $\begin{array}{l}4.2 \\
4.0 \\
4.6 \\
5.1 \\
4.1\end{array}$ & $\begin{array}{l}7.2 \\
6.4 \\
6.9 \\
5.8 \\
5.4\end{array}$ & $\begin{array}{l}4.5 \\
4.4 \\
4.7 \\
5.0 \\
4.6\end{array}$ & $\begin{array}{r}3.8 \\
3.7 \\
5.8 \\
11.2 \\
13.3\end{array}$ & $\begin{array}{l}4.7 \\
4.7 \\
4.5 \\
5.2 \\
5.0\end{array}$ & $\begin{array}{l}4.5 \\
4.0 \\
4.7 \\
6.4 \\
5.9\end{array}$ & $\begin{array}{r}3.3 \\
5.7 \\
9.9 \\
13.0 \\
10.5\end{array}$ & $\begin{array}{l}5.0 \\
5.3 \\
5.2 \\
5.5 \\
3.7\end{array}$ & $\begin{array}{l}4.2 \\
4.6 \\
5.8 \\
6.4 \\
5.3\end{array}$ & \begin{tabular}{l}
3.7 \\
4.4 \\
4.9 \\
\hdashline 4.3
\end{tabular} & $\begin{array}{l}5.6 \\
5.4 \\
5.4 \\
-4.8\end{array}$ & $\begin{array}{r}4.4 \\
4.3 \\
4.5 \\
-4.4\end{array}$ \\
\hline $\begin{array}{l}1,300^{8} \\
1,300 \text { (slow cooling) }^{4} \\
1,300 \text { (plus alumina) } \\
1,400\end{array}$ & $\begin{array}{l}4.5 \\
6.2 \\
6.6 \\
4.7\end{array}$ & $\begin{array}{l}6.8 \\
7.5 \\
9.5 \\
5.7\end{array}$ & $\begin{array}{l}4.5 \\
4.9 \\
6.9 \\
4.4\end{array}$ & $\begin{array}{l}3.5 \\
4.4 \\
5.8 \\
3.6\end{array}$ & $\begin{array}{l}4.9 \\
5.5 \\
7.4 \\
4.8\end{array}$ & $\begin{array}{l}4.4 \\
4.5 \\
6.2 \\
4.3\end{array}$ & $\begin{array}{r}15.7 \\
15.7 \\
7.5 \\
15.7\end{array}$ & $\begin{array}{l}5.4 \\
5.8 \\
6.3 \\
5.7\end{array}$ & $\begin{array}{l}6.5 \\
6.8 \\
6.4 \\
6.5\end{array}$ & $\begin{array}{r}6.1 \\
13.9 \\
5.0 \\
3.6\end{array}$ & $\begin{array}{l}5.1 \\
5.5 \\
6.5 \\
4.1\end{array}$ & $\begin{array}{l}4.7 \\
6.4 \\
5.8 \\
4.2\end{array}$ & \begin{tabular}{r}
3.9 \\
\hdashline 4.5 \\
3.8
\end{tabular} & $\begin{array}{l}5.0 \\
6.3 \\
4.5\end{array}$ & $\begin{array}{l}4.3 \\
5.6 \\
4.2\end{array}$ \\
\hline $\begin{array}{l}1,400 \text { (slow cooling) } \\
1,500 \\
1,650 \\
1,650 \text { (plus alumina) }\end{array}$ & $\begin{array}{l}4.2 \\
3.7 \\
3.7 \\
4.5\end{array}$ & $\begin{array}{l}5.7 \\
4.4 \\
4.1 \\
5.8\end{array}$ & $\begin{array}{l}4.6 \\
3.9 \\
4.1 \\
5.2\end{array}$ & $\begin{array}{l}3.7 \\
3.8 \\
4.0 \\
4.7\end{array}$ & $\begin{array}{l}4.9 \\
4.5 \\
4.8 \\
6.0\end{array}$ & $\begin{array}{l}4.4 \\
4.3 \\
4.6 \\
5.5\end{array}$ & $\begin{array}{r}19.9 \\
16.4 \\
3.6 \\
3.6\end{array}$ & $\begin{array}{l}5.9 \\
5.3 \\
4.5 \\
4.6\end{array}$ & $\begin{array}{l}7.1 \\
6.5 \\
4.0 \\
4.4\end{array}$ & $\begin{array}{r}11.0 \\
5.7 \\
3.8 \\
4.4\end{array}$ & $\begin{array}{l}5.6 \\
5.1 \\
4.8 \\
5.7\end{array}$ & $\begin{array}{l}6.0 \\
5.1 \\
4.0 \\
5.3\end{array}$ & $\begin{array}{l}3.8 \\
3.8 \\
4.4\end{array}$ & $\begin{array}{l}4.4 \\
4.5 \\
5.8\end{array}$ & $\begin{array}{l}4.2 \\
4.3 \\
5.3\end{array}$ \\
\hline
\end{tabular}

1 Values to be multiplied by $10^{-\bullet}$.

To obtain percentage expansion at $900^{\circ} \mathrm{C}$., multiply the value given in the column beaded " 20 to 900 " by 880 and divide by $10^{4}$.

Specimens were withdrawn at the temperatures indicated and cooled comparatively rapidly.

1 Specimens held at the temperatures indicated for a short time as noted in the text and then were allowed to cool with the furnace, therefore, cooled comparatively slowly.

S Specimens containod added percentages of precipitated alumina.

In general, the curves for North Carolina and Delaware kaolins and the English china clay are similar and for convenience may be classified in one group and those for the Georgia and Zettlitz kaolins in a second. The curves on the left in Figures 1 and 2 represent the expansion data of the kaolins after rapid cooling, while those on the right are the same kaolins after slow cooling. The curves in Figure 1 , which give the expansion data of the first group, show very little difference in either the type or the total expansion of the three clays. The North Carolina kaolin shows the greatest increase in expansion between $575^{\circ}$ and $600^{\circ}$ C., due to the inversion of $\alpha$ to $\beta$ quartz. Both the Delaware and English clays show this same inversion at the 
lower firings, but to a lesser degree. The data for the North Carolina and Delaware kaolins indicate that the rate of cooling has compara-
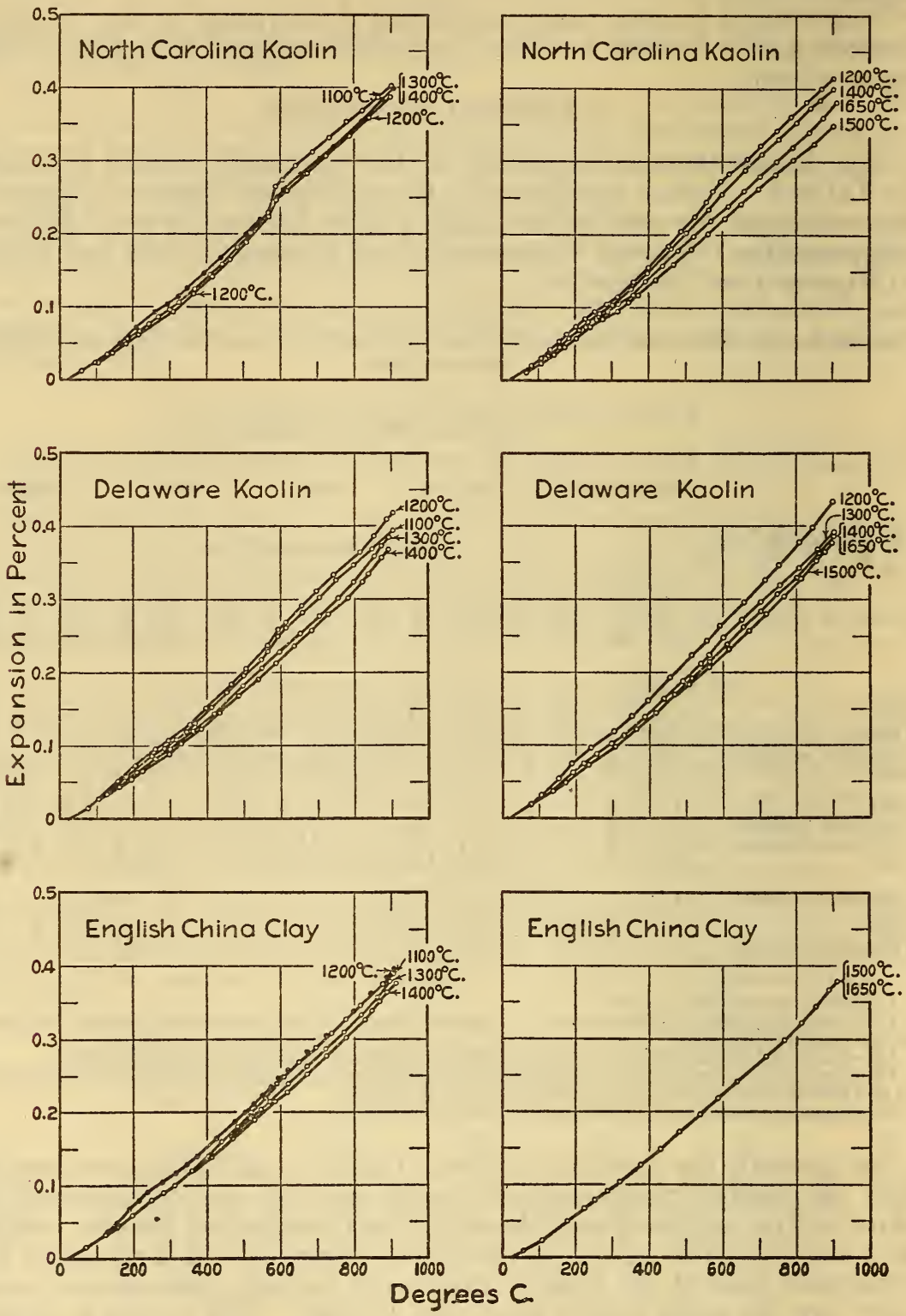

FIGURE 1.-The thermal expansion curves of one group of kaolins after firing at several different temperatures

The curves on the left were obtained when the clays were cooled rapidly and those on the right when held at the maximum temperature for a short time and cooled slowly.

tively little effect on the thermal expansion of these clays after having been fired to the same temperatures. 
The thermal expansions of the Georgia and Zettlitz kaolins which are shown in Figure 2 are decidedly different from the three kaolins shown in Figure 1. Progressively increasing the temperature of firing has a marked effect on the expansivity of the Georgia and Zettlitz kaolins below $200^{\circ} \mathrm{C}$. The pronounced variation in rate is undoubtedly due to mineralogical changes occurring in the clays which, in

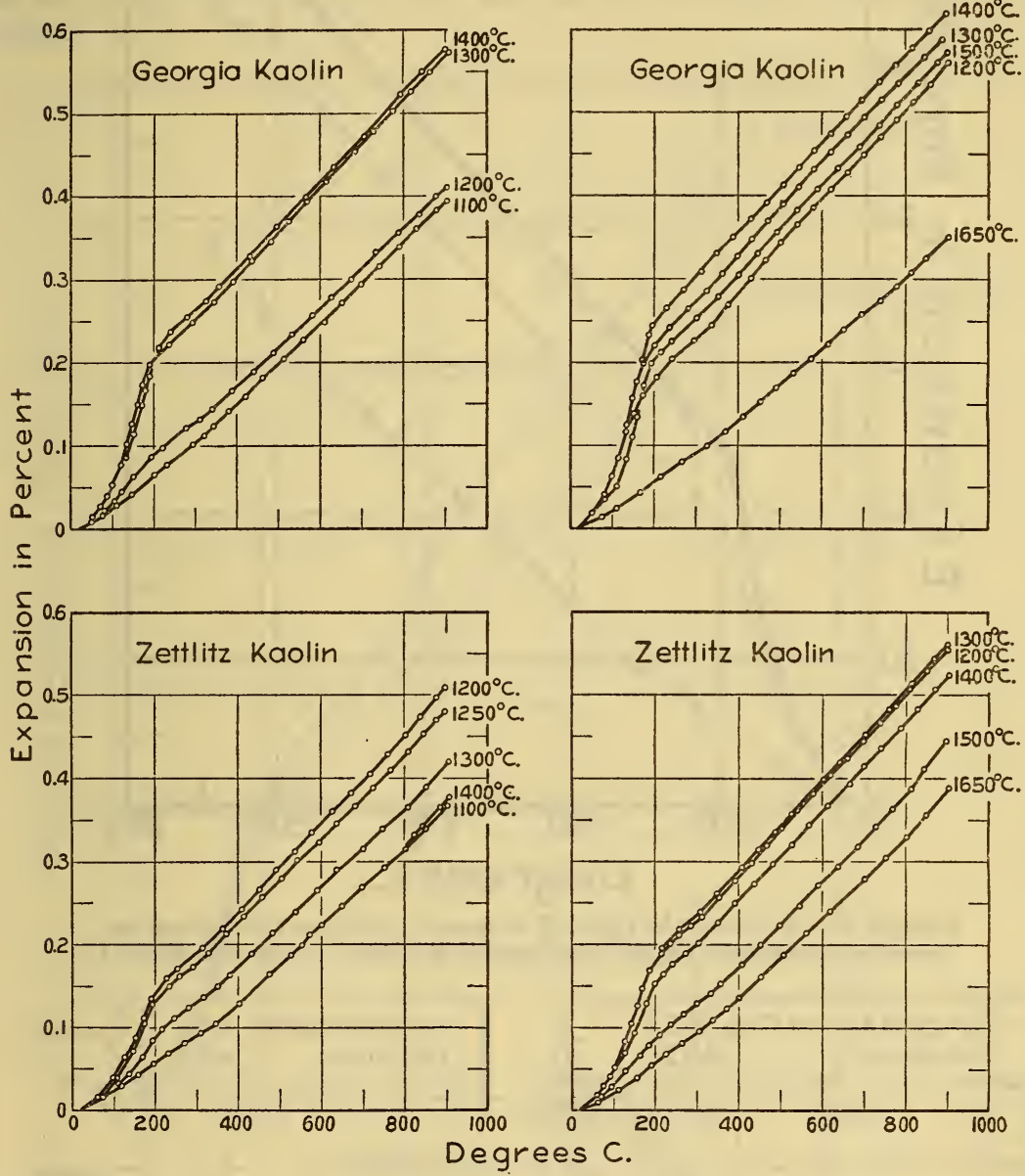

FIgURE 2.-The thermal expansion curves of a second type of kaolins after firing at several different temperatures

The rate of cooling (rapid cooling on the left) after firing at certain temperatures has a decided effect on the expansion.

turn, are affected by the relative purity. As shown by the curves on the left in Figure 2, the Georgia kaolin shows a slightly higher total expansion after firing at $1,200^{\circ} \mathrm{C}$. than after $1,100^{\circ} \mathrm{C}$. However, after firing at $1,250^{\circ}$ (not shown in the figure), $1,300^{\circ}$, and $1,400^{\circ} \mathrm{C}$., the expansion below $200^{\circ} \mathrm{C}$. has increased to its maximum, but is practically the same for the three firings. The Zettlitz kaolin under corresponding conditions of firing shows the greatest increase in expansion after the firing to $1,200^{\circ} \mathrm{C}$. As the temperature of firing 


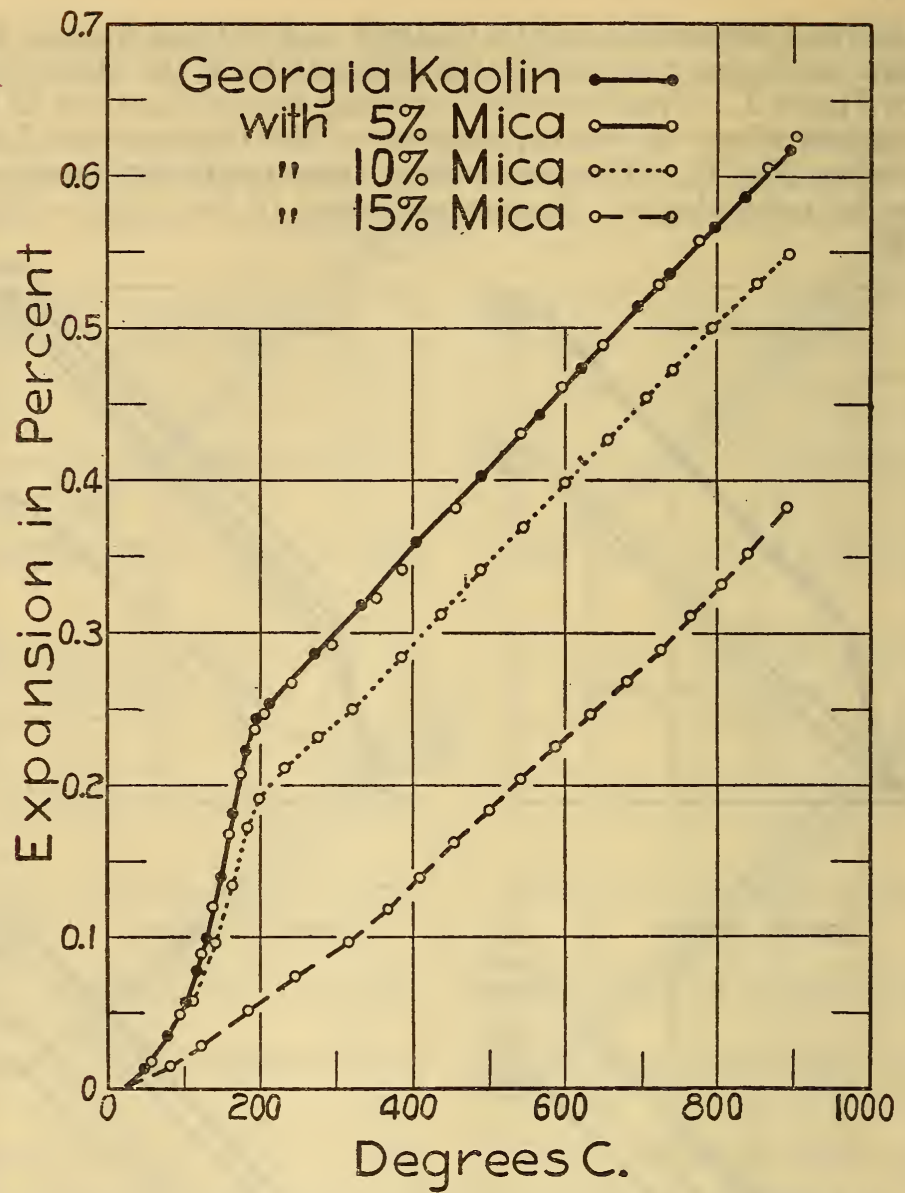

FIGURE 3.- Showing the effect of muscovite mica on the thermal expansion of Georgia kaolin after firing at $1,400^{\circ} \mathrm{C}$. for five hours

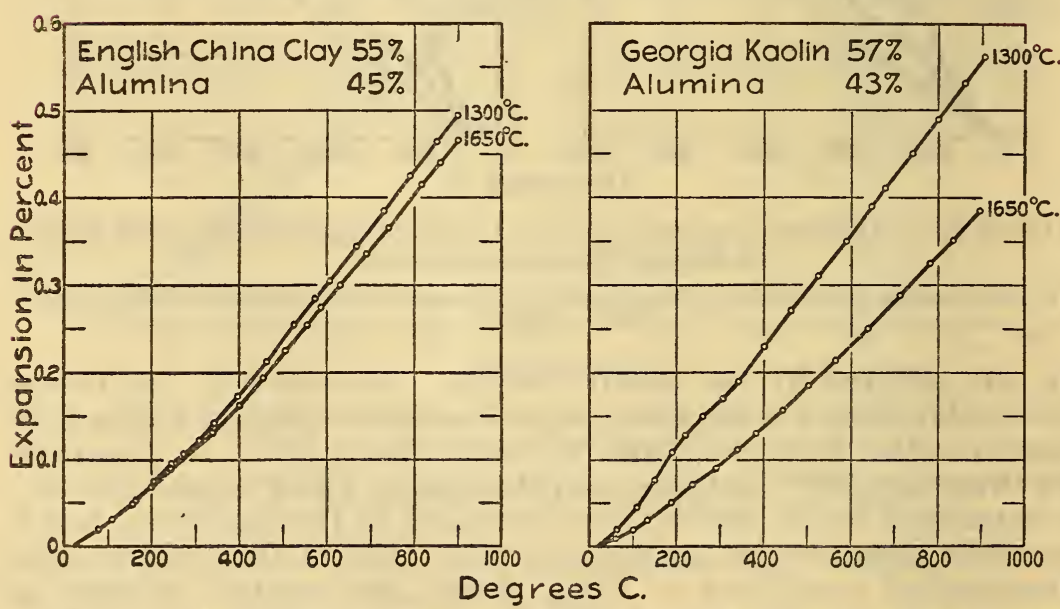

FIGURE 4.-The effect of alumina on the thermal expansion of kaolins having two different types of expansion after firing 
was increased the total thermal expansion gradually decreased so that after firing at $1,400^{\circ} \mathrm{C}$. the expansion was practically the same as after the firing at $1,100^{\circ} \mathrm{C}$. The petrographic examination shows the Georgia and Zettlitz kaolins to be very nearly the same as far as clay content, mica, quartz and feldspar are concerned. The chemical analysis shows the Georgia kaolin to have appreciably more titanium oxide (rutile) than the Zettlitz kaolin, but the alkalies are decidedly greater in the latter.

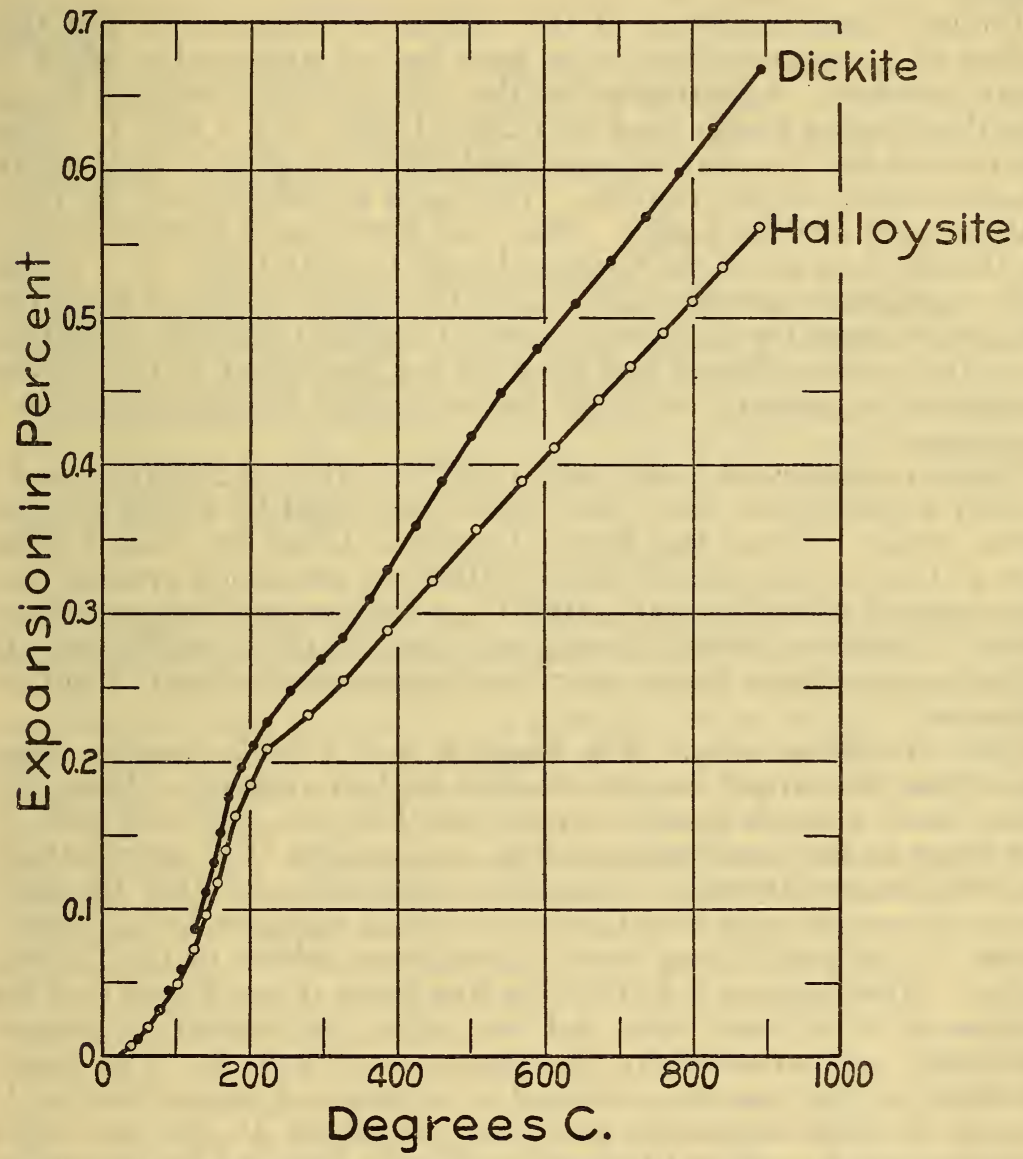

FIGURE 5.-Thermal expansion curves of dickite and halloysite after firing at $1,300^{\circ} \mathrm{C}$. for two hours

The sample of dickite was hand-picked and unusually pure.

Comparing the information obtained from the petrographic analysis and thermal expansion data of these two fired kaolins, the following differences are noted. In all probability these differences are the result largely of the greater amount of alkalies present in the Zettlitz kaolin.

1. The first indication of the formation of cristobalite in the Zettlitz clay from the excess of silica developed as a result of the conversion of the clay to mullite, occurred at $1,200^{\circ}$ as against $1,250^{\circ} \mathrm{C}$. in the Georgia kaolin. 
2. The temperature at which the maximum amount of cristobalite is formed in the Zettlitz kaolin is approximately $200^{\circ} \mathrm{C}$. below that at which the maximum was formed in the Georgia kaolin.

3. The maximum amount of cristobalite present in the Zettlitz kaolin after any firing is decidedly less than that obtained in the Georgia kaolin.

4. The cristobalite is changed to a glass at a considerably lower temperature and at a greater rate in the Zettlitz kaolin than in the Georgia.

Holding these specimens at the maximum temperature and then cooling at a comparatively slow rate has an appreciable effect on their expansion. A comparison of the corresponding curves in Figure 2 for the Georgia kaolin fired at $1,200^{\circ}, 1,300^{\circ}$, and $1,400^{\circ} \mathrm{C}$. shows that in each case the slower cooled material has a greater total expansion than when cooled rapidly. The same statement may be made relative to the Zettlitz kaolin. The most pronounced difference noted was that in the case of the Georgia kaolin fired at 1,200 ${ }^{\circ} \mathrm{C}$. Apparently, therefore, approximately, $1,200^{\circ} \mathrm{C}$. is in this instance the favorable temperature for the development of mullite under the conditions prevailing, since sufficient free silica for the production of the amount of cristobalite present can only be accounted for through such a development.

The temperatures of $1,500^{\circ}$ and $1,650^{\circ} \mathrm{C}$. given in Figures 1 and 2 are only approximate, since they were determined by means of pyrometric cones. Firing the North Carolina, Delaware, and English clays at these temperatures did not alter the expansion greatly from that obtained after firing at $1,400^{\circ} \mathrm{C}$., a uniform and low rate being shown. However, firing the Georgia and Zettlitz kaolins at the highest temperatures lowers their total expansion decidedly from the maximum.

Effect of adding mica.-The Georgia and Zettlitz kaolins stand apart from the other kaolins studied in two respects. First, the former show a much greater expansivity between $100^{\circ}$ and $200^{\circ} \mathrm{C}$. after firing at the lower temperatures, and second, they are relatively free from muscovite mica. In order to determine whether the addition of muscovite mica might reduce the high expansivities of certain kaolins, 5, 10, and 15 per cent of mica were added to the Georgia kaolin. After firing at $1,400^{\circ} \mathrm{C}$. for five hours it was found that the addition of 5 per cent mica did not affect the thermal expansion appreciably as indicated by the curves in Figure 3 . The kaolin containing 10 per cent mica showed a reduction of approximately 12 per cent in total expansion and that containing 15 per cent mica approximately 37 per cent reduction, thereby bringing the expansion close to that of North Carolina, Delaware, and English kaolins after firing at the same temperature. These data indicate that the mica present in kaolins evidently has a decided effect on their expansion. This is an effect which might be expected if the added mica dissolves or prevents the cristobalite formation.

Effect of adding alumina.- The purpose of adding alumina to the kaolins was (1) to permit the formation of mullite by a combination of the added alumina and free silica resulting during the firing of clays and (2) to determine its effect on the thermal expansion. The data obtained on the thermal expansion after firing at two different temperatures are given in Table 3 and expansion curves of the English 
and Georgia kaolins are given in Figure 4. The alumina tends to make the rate of expansion uniform throughout the entire range from $20^{\circ}$ to $900^{\circ} \mathrm{C}$. for the two kaolins showing a high rate of expansion below $200^{\circ} \mathrm{C}$. after firing at $1,200^{\circ} \mathrm{C}$. and by so doing causes the average coefficient of expansion to be lowered. The three kaolins which do not have the high rate of expansion below $200^{\circ} \mathrm{C}$. show an increased rate of expansion because of the added alumina. In all cases the kaolins with the added alumina show a slightly higher expansivity after firing at cone 30 than the kaolin having no added alumina.

Additional materials.-The thermal expansion was measured of a specimen of Georgia hard kaolin fired at $1,300^{\circ} \mathrm{C}$. The data obtained were so nearly identical with those obtained on the Georgia soft kaolin included in this study that no other data were obtained. Samples of dickite ${ }^{7}$ and halloysite were also fired at $1,300^{\circ} \mathrm{C}$. and the expansion measured. (Fig. 5.) The halloysite has practically the same total expansion as the Georgia kaolin, but the dickite has a decidedly greater total expansion than any of the other kaolins studied. Both materials have a high rate of expansion below $200^{\circ}$ C. similar to that shown by the Georgia kaolin.

Duplicate determinations of the thermal expansions were made on 27 specimens in which each of the five kaolins were represented. The greatest variation in data obtained on the same material was less than $\pm 2 \frac{1}{2}$ per cent.

\section{X-RAY STUDIES}

Although it has long been assumed that the increased rate of expansion often observed in clay products between $100^{\circ}$ and $200^{\circ} \mathrm{C}$. is caused by the inversion of one form of cristobalite to another, no definite evidence has ever been presented to establish that assumption as a fact. A question arises as to the correctness of such an assumption because existing data ${ }^{8}$ indicate that the inversion of the low cristobalite to high cristobalite occurs between $200^{\circ}$ and $275^{\circ} \mathrm{C}$. approximately. Westman ${ }^{9}$ made computations from expansion data to show that the inflections occurring below $200^{\circ} \mathrm{C}$. in the thermal expansion curves of fire-clay brick were probably due to the presence of cristobalite. The expansion curve given in Figure 5 for the form of kaolinite known as dickite shows the high rate of expansion to occur between approximately $110^{\circ}$ and $210^{\circ} \mathrm{C}$. The petrographic examination of the raw material indicated it to be free from impurities. The increased rate of expansion between $110^{\circ}$ and $210^{\circ} \mathrm{C}$. is therefore very probably due to the excess silica occurring as a result of the development of mullite from the clay. The petrographic microscope has failed to indentify the cristobalite as such because of its fine-grained state and because it is present as an interstitial material. X-ray diffraction patterns were made of the North Carolina kaolin, which showed a uniform rate of expansion throughout the range $\left(20^{\circ}\right.$ to $900^{\circ} \mathrm{C}$.) studied, and of both the Georgia and Mexican (dickite) kaolins, which show a high rate of expansion between approximately $100^{\circ}$ and $210^{\circ} \mathrm{C}$. and a comparatively low and uniform

7 Described in detail in "The Kaolin Minerals," by C. S. Ross and P. F. Kerr, U. S. Geological Survey Professional Paper $165 \mathrm{E}$

8 Robert B. Sosman, The Properties of Silica.

A. E. R. Westman, The Thermal Expansion of Fire-Clay Bricks, Univ. Ill. Bull. No. 181. 
rate from $210^{\circ}$ to $900^{\circ} \mathrm{C}$. For purposes of comparison X-ray diffraction patterns were also made of mullite and cristobalite.

The patterns of the North Carolina kaolin fired at $1,300^{\circ} \mathrm{C}$. showed nothing but the typical mullite pattern indicating that the silica was present in noncrystalline form, a condition which would account for the fact that there is no inflection in the expansion curve below $200^{\circ}$ C. The Georgia kaolin as well as the dickite fired at $1,300^{\circ} \mathrm{C}$. showed the diffraction pattern of mullite as well as that of cristobalite. The X-ray patterns of the Georgia kaolin (center), mullite (top), and cristobalite (bottom) are given in Figure 6. The Georgia kaolin shows only the patterns of mullite and cristobalite. The information thus obtained definitely establishes the fact that the high and increased rate of expansion between approximately $100^{\circ}$ and $200^{\circ} \mathrm{C}$. in refractory clays is primarily caused by the presence of cristobalite.

\section{SIMILARITY OF EXPANSION BETWEEN $100^{\circ}$ AND $200^{\circ} \mathrm{C}$. OF PRECIPITATED SILICA AND THE GEORGIA AND ZETTLITZ KAOLINS}

Specimens prepared from silicic acid and also from potters flint were fired at $1,300^{\circ} \mathrm{C}$. for two hours and a second set at $1,400^{\circ} \mathrm{C}$. for five hours. The silicic acid was the C. P. grade and the flint, which was ground to pass a 200-mesh sieve, came from Illinois.

The petrographic examination indicated that the silicic acid or precipitated silica had been apparently wholly converted to cristobalite. The powder X-ray diffraction pattern confirmed the results of the petrographic examination. No lines other than those of cristobalite were noted in the pattern.

The petrographic examination of the flint fired at $1,300^{\circ} \mathrm{C}$. showed it to be composed almost entirely of crystalline quartz with some indications of initial formation of what apparently was cristobalite. The X-ray diffraction pattern gave similar information. Examination after firing at $1,400^{\circ} \mathrm{C}$. showed less quartz and more cristobalite.

The expansion data obtained on these materials are represented by the curves in Figure 7 . Greatly increased rates of expansion of the specimen of flint occur between $200^{\circ}$ and $240^{\circ} \mathrm{C}$. and again between $555^{\circ}$ and $575^{\circ} \mathrm{C}$. These increases in the rate of expansion begin presumably with or just before the cristobalite and quartz inversions. The curve for silicic acid after firing at $1,300^{\circ} \mathrm{C}$. shows that a very high rate of expansion occurs between $150^{\circ}$ and $195^{\circ} \mathrm{C}$., but from $200^{\circ}$ to $900^{\circ} \mathrm{C}$. the rate is much lower and, in general, the entire curve is about the same as that obtained of the Georgia and Zettlitz kaolins after firing at certain temperatures. (See fig. 2.) Various investigators ${ }^{10}$ have reported the transformation of precipitated silica to cristobalite at comparatively low temperatures. Houldsworth and $\mathrm{Cobb}{ }^{11}$ reported expansion data on precipitated silica after the transformation to cristobalite similar to those obtained on the silicic acid fired at $1,300^{\circ} \mathrm{C}$.

The high rate of expansion and greatly increased total expansion observed between $175^{\circ}$ and $230^{\circ} \mathrm{C}$. approximately, in the specimen

10 Robert B. Sosman, The Properties of Silica, pp. 166-176.

11 H. S. Houldsworth and J. W. Cobb; The Reversible Thermal Expansion of Silica, Trans. Eng. Cer. Soc., vol. 21, pp. 227-276; 1921 . 
B. S. Journal of Research, RP410

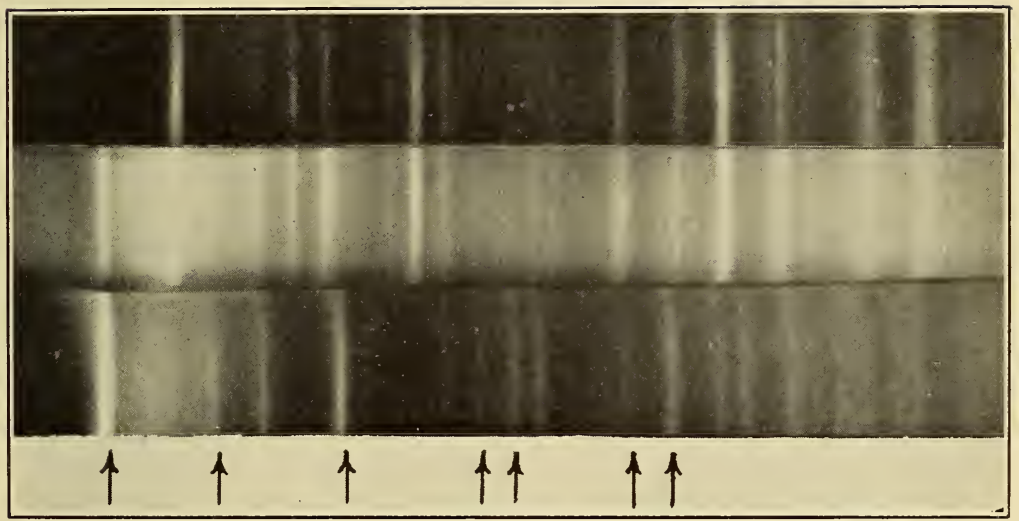

Figure 6.-X-ray diffraction patterns of Georgia kaolin (center), mullite (top), and cristobalite (bottom)

Arrows point to the lines of cristobalite which are clearly visible in the diffraction pattern of the kaolin. Unmarked lines in the cristobalite pattern are either so faint that they are not definite or are coincident or nearly coincident with mullite lines. The mullitelines in the kaolin pattern may readily be matched with those in the pattern of the pure mullite. 


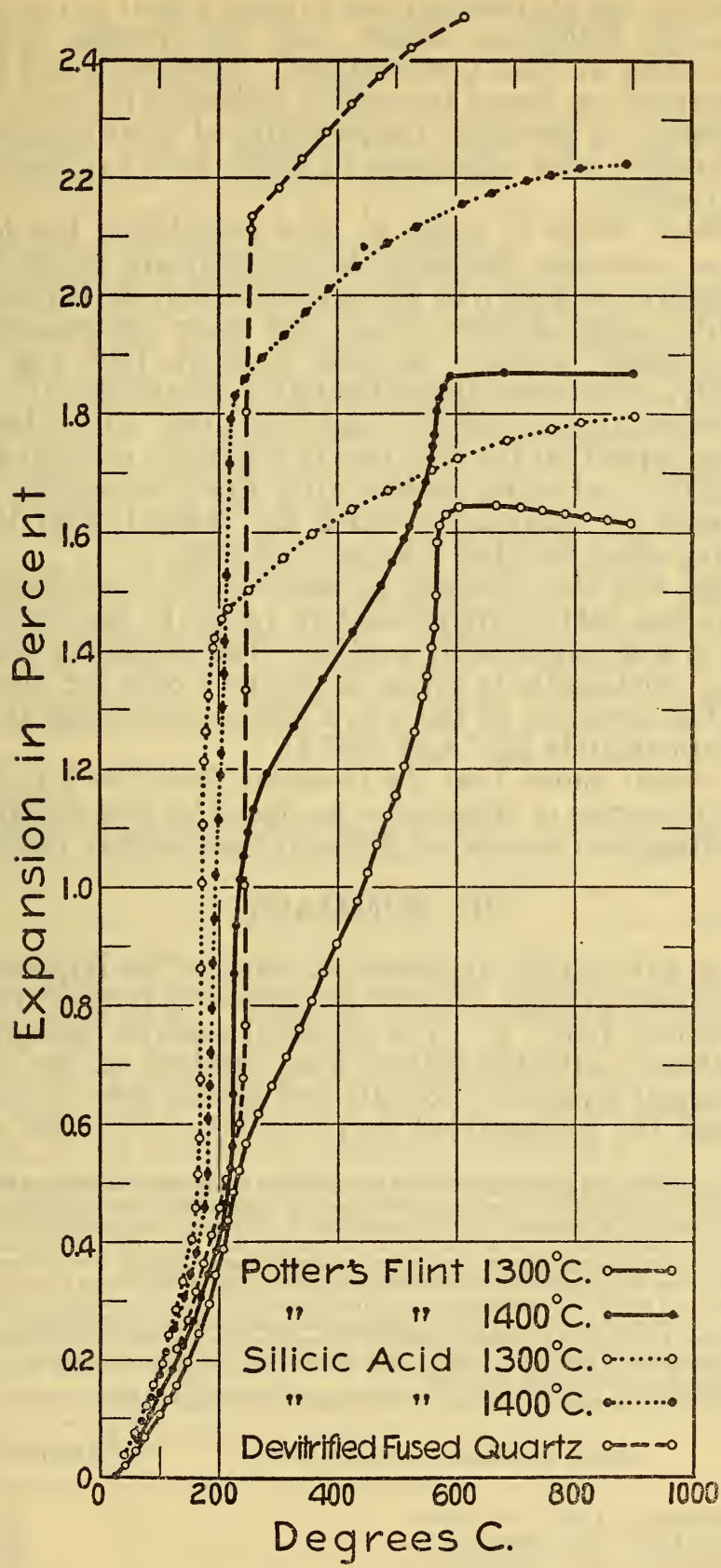

FIGURE 7.-The thermal expansion of precipitated amorphous silica, crystalline silica (fint) after firing at $1,300^{\circ}$ and $1,400^{\circ} \mathrm{C}$., and devitrified fused quart $z$ 
fired at $1,400^{\circ} \mathrm{C}$. are also comparable to some extent to the expansion obtained on the halloysite, dickite, and the Georgia and Zettlitz kaolins after firing at some temperatures. (See figs. 2 and 5.)

An explanation was found for neither difference in total expansion nor the difference in inversion temperatures of what apparently was wholly cristobalite after specimens of silicic acid had been fired at $1,300^{\circ}$ and $1,400^{\circ} \mathrm{C}$.

The inversion range of alpha to beta cristobalite has long been recognized as occurring between the approximate limits $200^{\circ}$ and $275^{\circ} \mathrm{C}$. However, as shown by the present study, the inversion range of cristobalite prepared from silicic acid when determined by the expansion method ${ }^{12}$ appears to occur between $150^{\circ}$ and $195^{\circ} \mathrm{C}$., approximately, or between approximately $175^{\circ}$ and $230^{\circ} \mathrm{C}$., depending on the temperature at which it had been fired. It has been shown earlier in this paper that the high rate of expansion occurring between $100^{\circ}$ and $210^{\circ} \mathrm{C}$. of some kaolins after firing at certain temperatures is caused by cristobalite which has formed from the excess silica resulting when the clay changes to mullite.

Cristobalite was also obtained by devitrifying fused quartz. The fused quartz was held at approximately $1,625^{\circ} \mathrm{C}$. for one-half hour, after which it was cooled fairly rapidly. The expansion obtained on the resulting cristobalite is given in Figure 7 only for comparative purposes. The inversion of the $\alpha$ to $\beta$ cristobalite occurs in this case between approximately $235^{\circ}$ and $255^{\circ} \mathrm{C}$.

Figure 7 clearly shows that the inversion from the $\alpha$ to $\beta$ form of four different samples of cristobalite produced by four different methods occur within four somewhat different temperature ranges.

\section{SUMMARY}

Samples of five kaolins, representing some of the important world sources, were fired at eight different temperatures ranging from $1,100^{\circ}$ to approximately $1,650^{\circ} \mathrm{C}$. The chemical analyses and pyrometric cone equivalents (softening points) were obtained on the raw materials, the thermal expansion, porosity and specific gravity on the fired materials, and the petrographic analyses on both the raw and fired.

12 This difference between the accepted values for the inversion temperatures and those which might be chosen in view of the temperature range of the increased rate of thermal expansion probably arises from the fact that there is a measurable increase in the expansion rate throughout a considerable temperature range just preceding that in which there is a detectable increase in the heat absorption on heating.

The accepted values for the inversion temperatures are usually based on heat effect determinations and the temperatures chosen are presumably those where the rates of heat absorption or evolution are greatest and these temperatures usually fall reasonably near those where the rates of expansion or contraction are at their maxima. In the case of clear-cut heat effects the maximum rate of heat absorption or evolution is always within a very few degrees of the temperatures determined, respectively, by the minimum of the heating and the maximurn of the cooling curve. Such maxima and minima as determined by A. Q. Tool for four of the above specimens are given below.

Temperatures corresponding to the maxima and minima of the cooling and heating curves, respectively:

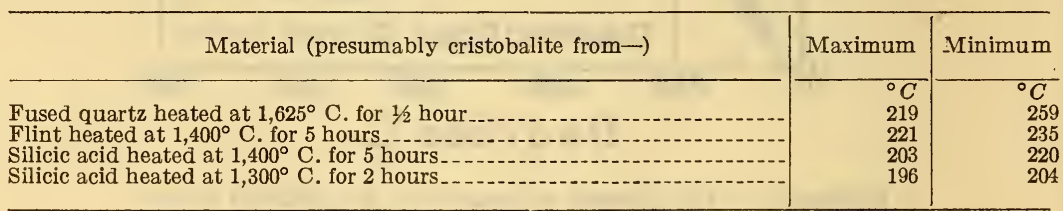

The heat effects both on heating and cooling were large and very clear-cut in the case of the fused quartz specimen. For the flint they were much smaller and only reasonably clear-cut. In the cases of both silicic acid specimens they were somewhat smaller still, and the minima of the heating curves were not well defined. This lack of definiteness was of such a character that it suggests the possibility of a mixture of crystal forms. 
X-ray diffraction patterns were made of Georgia, North Carolina, and Mexican (dickite) kaolins, mullite, and cristobalite.

The following results were noted:

1. The chemical and petrographic analyses show the Georgia, and Zettlitz kaolins to be of greater purity than the North Carolina and Delaware kaolins or the English china clay.

2. The specific gravity of the Georgia and Zettlitz kaolins is, in general, higher than that of the other three.

3. The porosity of the North Carolina kaolin is the highest and shows the least change over the range of temperature used.

4. After firing the purer Georgia and Zettlitz kaolin at some temperatures, the linear thermal expansion between approximately $100^{\circ}$ and $200^{\circ} \mathrm{C}$. is decidedly greater than that of the other three.

5. Progressively increasing the firing temperature of the kaolins affects the thermal expansion of those containing the greater amount of foreign material to a less extent than it does those of higher purity. The former are also affected less by changes in the rate of cooling.

6. Addition of 15 per cent muscovite to the Georgia kaolin did not measurably affect its P. C. E. (softening point), but after firing at $1,400^{\circ} \mathrm{C}$. the thermal expansion of the mixture was greatly reduced when compared with that obtained on the kaolin alone after firing at the same temperature. Addition of alumina in amounts based on the quantity of free silica present increased the mullite to almost 100 per cent when certain of the materials were fired at the highest temperature.

7. Evidence is given which indicates that the high rate of expansion shown by certain fired refractory clays is primarily caused by the presence of cristobalite. This cristobalite may form as a result of (a) free quartz in the unfired material or (b) excess silica from the reaction involving the formation of mullite from clay.

8. X-ray diffraction patterns show the presence of cristobalite in one of the fired clays. The high rate of expansion caused by the inversion of the $\alpha$ to $\beta$ form begins approximately $75^{\circ} \mathrm{C}$. below the usually accepted lower limit of the temperature range of this inversion.

9. The high rate of expansion between approximately $100^{\circ}$ and $210^{\circ} \mathrm{C}$. due to the presence of cristobalite in some of the fired kaolins is similar to the expansion of cristobalite prepared from precipitated amorphous silica which also occurs between approximately $100^{\circ}$ and $210^{\circ} \mathrm{C}$.

\section{ACKNOWLEDGMENTS}

Acknowledgment is due Dr. Herbert Insley for making the X-ray photographs and interpreting the diffraction patterns and also for his work and that of R. H. Ewell on the petrographic analyses.

Washington, December 5, 1931. 